\title{
Anti-Toxoplasma activity of Sorghum bicolor-derived lipophilic fractions
}

\author{
Daniel A. Abugri ${ }^{*}$, Jesse M. Jaynes ${ }^{2}$ and William H. Witola ${ }^{3}$
}

\begin{abstract}
Objective: Toxoplasma gondii, an intracellular zoonotic parasite, infects approximately a third of the world population. Current drugs for treatment of T. gondii infection have been challenged with ineffectiveness and adverse side effects. This necessitates development of new anti-Toxoplasma drugs. Sorghum bicolor [Moench] leaf extract has been used in African traditional medicine for the management of anemia and treatment of infectious diseases. We tested the in vitro anti-Toxoplasma inhibitory activity of S. bicolor's oil-like crude extracts and fractions against T. gondii and determined their cytotoxic effects on human host cells.

Results: Significant inhibitory activities against the growth of T. gondii tachyzoites were observed for the crude extract $\left(I C_{50}=3.65 \mu \mathrm{g} / \mathrm{mL}\right)$, the hexane-methanol fraction $\left(I C_{50}=2.74 \mu \mathrm{g} / \mathrm{mL}\right)$, and the hexane fraction $(\mathrm{IC} 50=3.55 \mu \mathrm{g} / \mathrm{mL})$ after $48 \mathrm{~h}$ of culture. The minimum cytotoxicity concentrations against HFF were 34.41, 16.92 and $7.23 \mathrm{\mu g} / \mathrm{mL}$ for crude extract, hexane-methanol and hexane fractions, respectively. The crude extract and fractions showed high antiparasitic effects with low cytotoxic effects. Further studies to determine synergistic activities and modes of action would provide impetus for the development of new toxoplasmosis drugs or nutraceuticals.
\end{abstract}

Keywords: Sorghum bicolor, Oil-like extracts/fractions, Chemical composition, Anti-Toxoplasma activity

\section{Introduction}

Toxoplasma gondii is an opportunistic, zoonotic, obligate intracellular coccidian protozoa affecting almost all warm-blooded and cold-blooded vertebrates [1, 2]. Globally, it is estimated that $30-50 \%$ of the human population is infected with T. gondii [3], with the most vulnerable being pregnant women, fetuses, infants, and immunocompromised individuals such as those with HIV-AIDS or those undergoing organ transplant or cancer therapy [4]. T. gondii can be acquired in various ways including ingestion of contaminated raw meat, unwashed vegetables, unpasteurized milk, contaminated water, as well as poor animal care and housing systems $[5,6]$. The rate of infection and prevalence of the parasite in warm and cold-blooded vertebrates, poses medical, veterinary, food safety, public health, socio-economic and bioterrorism

\footnotetext{
*Correspondence: dabugri@tuskegee.edu

1 Department of Chemistry and Department of Biology, Laboratory of Ethnomedicine, Parasitology and Drug Discovery, College of Arts and Sciences, Tuskegee University, Tuskegee, AL, USA

Full list of author information is available at the end of the article
}

concerns globally $[1,7,8]$. For instance, about $22.5 \%$ of the US population aged 12 years and above have come in contact with the parasite [9]. Toxoplasmosis, the disease caused by $T$. gondii, has been reported to be the second leading cause of food-borne deaths in the US [9], and to cost the US economy about US $\$ 7.7$ billion annually [10].

Current standard drugs used for treatment of Toxoplasma gondii infection are pyrimethamine, sulfadiazine or a combination of pyrimethamine and sulfadiazine [11-13]. However, these drugs have been reported to have limitations such as being ineffective in killing the encysted form of the parasite, and being toxic [14-16]. Hence, alternative drugs or nutraceuticals are urgently needed for treatment of toxoplasmosis. Plant-derived bioactive compounds have huge potentials as new alternatives lead-compounds for developing new generation of safe and effective drugs against T. gondii, partly due to documented evidence about their antimicrobial activities [17]. Sorghum bicolor [Moench] is a member of the Poaceae, or grass family, and is most closely allied to grass crops like sugarcane and maize. S. bicolor plant and its parts are rich in fatty acids, phenolics, flavonoids, 
peptides, iron, tannins, 3-deoxyanthocyanidins, anthocyanidins and anthocyanins, among others [18-23]. Many traditional herbal formulations have been made from its leaves and used to treat various ailments [18, 20-22]. Additionally, S. bicolor red leaves are used as food and drink colorant, dyes for making hats and clothing, for production of potassium hydroxide, while the flour from the seeds is used for making local cakes and beer in Nigeria and northern Ghana [20, 21]. Recently, our group discovered 3-deoxyanthocyanidins compounds that were extracted with ethanol from the $S$. bicolor to have remarkable anti-Toxoplasma gondii [22]. However, little is known scientifically about the identity, composition, and potential anti-parasitic effects of S. bicolor red leaves' oil-like extracts and fractions. The objective of this study was to evaluate the efficacy of oil-like extracts and fractions obtained from $S$. bicolor red leaves against $T$. gondii proliferation in vitro, and to test their cytotoxicity.

\section{Main text}

Materials and methods

Plant material

Sorghum bicolor red leaves were obtained from Northern Ghana, West Africa as previously reported in detail [22].

\section{Preparation of crude extracts and fractions}

The $S$. bicolor leaf was extracted using procedures reported previously [20,22, 24]. Briefly, about 41 g dried powdered leaves were extracted with $500 \mathrm{~mL}$ of $99 \%$ ethanol for $2 \mathrm{~h}$ at $30^{\circ} \mathrm{C}$ with constant shaking at $100 \mathrm{rpm}$. The extraction was repeated three times and filtered. The crude filtrates were combined and dried using a rotatory evaporator. The solid crude extracts obtained were then washed with water, followed by $n$-hexane to obtained (12.07 g) reddish-yellow oil.

\section{Fractionation of compounds from crude extract}

The reddish yellow oil-like substance obtained from the $n$-hexane was passed through a size exclusion chromatography using (Biogel P 2 and P 60) with first eluded with hexane-methanol mixture (10:1). Afterwards, a pure hexane was passed through the column and the hexane fraction collected. Prior to the use of the pure hexane as eluent, other organic solvents were used but such fractions were not biologically active and thus were excluded in the chemical fingerprinting of the fractions obtained using such solvents. All the fractions collected were subjected to preparative thin layer chromatography (silica gel $60 \mathrm{~F}_{254 \mathrm{~nm}}, 0.2 \mathrm{~mm}$ : Merck) to confirm that there were differences in compound classes. Fractions with similar bands and retention factors were scrapped from the TLC plates, combined, and eluded using hexane-methanol mixture and pure hexane. All fractions were dried using a rotary evaporator. The dried crude extract and fractions were reconstituted in dimethyl sulfoxide (DMSO) for in vitro anti-parasitic and cell cytotoxicity assays.

\section{Electrospray ionization mass-spectrometry analysis of lipophilic crude extract and fractions}

Compounds were characterized using previously described procedure in [22]. Lipid species were identified using $\mathrm{m} / \mathrm{z}$ and structural information from the compound library including those of LipidMap (www. lipidmaps.org) and Avanti Polar Lipids (www.avantilipi ds.com). Quantitation of the unknown lipids from biological sample extracted from plants used standard lipids with known quantity analyzed by the same method using either the ion counts or the peak area.

\section{Maintenance of cell lines and parasites}

Human foreskin fibroblasts (HFF) were grown in Iscove's modified Dulbecco's medium (IMDM) made up of $10 \%$ (v/v) fetal bovine serum (FBS), $1 \%$ (v/v) Glutamax and 1\% $(\mathrm{v} / \mathrm{v})$ penicillin-streptomycin-fungizone obtained from (Life Technologies, USA) and incubated at $37{ }^{\circ} \mathrm{C}$ with $5 \%$ $\mathrm{CO}_{2}$ and $95 \%$ air. T. gondii (RH-YFP) strain tachyzoites were maintained in HFF cells for the growth inhibitory assays. To test our crude and fractions, we initially seeded HFF cells into 96 well plates using a total volume of $200 \mu \mathrm{L}$ of IMDM medium and allowed to grow to $100 \%$ prior to use.

\section{Evaluating T. gondii inhibitory activity}

In vitro anti-parasitic activity was defined by inhibition of parasite proliferation based on parasite fluorescence intensity. The confluent HFF cells were infected with RH-YFP T. gondii tachyzoites (3, 500 parasites $/ \mathrm{mL}$ ). Different concentrations of lipophilic crude extract and fractions were added to the cultures in triplicate immediately after parasite inoculation. DMSO was used as a control. At $48 \mathrm{~h}$ interaction of parasites, drugs and cells, parasite proliferation was determined with an automated Olympus IX71 fluorescence microscope. The parasite YFP fluorescence intensity was calculated using a free ImageJ software (NIH, USA). The $\mathrm{IC}_{50}$ of the lipophilic crude extract and fractions against $T$. gondii and cell lines were calculated using a free Graph Pad Prism.

\section{Statistical analysis}

The 96 well plates were monitored for parasites relative fluorescence units per well using confocal fluorescence microscopy at $48 \mathrm{~h}$ of interaction with test compounds. The crude extract and oil-like fractions concentrations in microgram per milliliters were transformed into log and plotted against parasites relative fluorescence units normalized into percent. The data were then analyzed using 
GraphPad Prism, and the 50\% inhibitory concentrations for the crude extract and oil-like fractionates against $T$. gondii and HFF cell lines were derived. The selectivity indexes (SI) for crude extract and fractions were calculated using the formula $=\mathrm{IC}_{50}$ cells $/ \mathrm{IC}_{50 \text { parasites }}$. All data are reported as three $(\mathrm{n}=3)$ independent experiments with their 95\% confidence intervals. Graph Pad T-test was used to compare difference between parasites $\mathrm{IC}_{50}$ values and cells $\mathrm{IC}_{50}$ values at $P<0.05$.

\section{Results}

In this study, we investigated S. bicolor red leaves reddish-yellow oil-like crude extract and fractions anti-Toxoplasma activity, as well as analyzed their cytotoxicity against an HFF cell line. The total yield of the reddishyellow oil-like crude extract obtained from $S$. bicolor red leaves was $29.44 \%$ on dry weight basis (DWB). The antiToxoplasma activity of the $S$. bicolor red leaf $n$-hexane crude extract, and those of the hexane-methanol (10:1) and $n$-hexane fractions obtained from the S. bicolor crude extract are presented in (Table 1). The compounds found in the crude reddish-yellow oil-like extract in significant amounts were benzoic, octanoic, nonadecanoic, linoleic, palmitic, stearic, oleic acids, arachidonic, ferulic, caffeic, quinic and jasmonic acid, as well as, luteolin, eugenol and apigenin (Table 1). Some of these compounds (e.g. benzoic, ferulic, caffeic, quinic, jasmonic acid, luteolin, and apigenin) are not usually found in lipophilic phase of plant extracts, however, we believed that their presence in the oil-like phase might have been due to incomplete evaporation of the water from the extratum.

In our quest to establish whether the crude extract and its fractionated compounds had potent activity against $T$. gondii, we measured their minimum inhibitory concentrations against $T$. gondii tachyzoites $\left(\mathrm{IC}_{50 \mathrm{p}}\right)$, and their cytotoxicity against HFF cells (Table 2). The crude $n$-hexane extract had significant activity against $T$. gondii with $\mathrm{IC}_{50 \mathrm{p}}$ value of $3.65 \mu \mathrm{g} / \mathrm{mL}$, and showed an HFF cytotoxicity $\left(\mathrm{IC}_{50 \mathrm{c}}\right)$ value of $34.41 \mu \mathrm{g} / \mathrm{mL}$, which was ninefold higher than its effective concentration against parasites (Table 2). At $48 \mathrm{~h}$, the $\mathrm{IC}_{50 \mathrm{p}}$ value $(2.74 \mu \mathrm{g} / \mathrm{mL}$ ) of the hexane-methanol fraction was lower than the value for the crude extract and the hexane fraction (Table 2), suggesting that the hexane-methanol fraction was more potently active against $T$. gondii. Importantly, the hexanemethanol fraction was less cytotoxic to HFF cells than the crude extract $\left(P^{<} 0.05\right)$ (Table 2). Cytotoxic effects of the three different oil-like fractions are summarized in Fig. 1a-c. Comparatively, all the compounds tested (crude extract and the fractions) had $\mathrm{IC}_{50 \mathrm{p}}$ values for $T$. gondii that were significantly lower than their respective cytotoxicity $\mathrm{IC}_{50}$ values in the HFF cell line $\left(P^{<} 0.05\right)$. Although, the hexane-methanol fraction had the lowest
Table 1 Chemical composition of the main constituents of the crude oil-like extract and its fractions obtained from dried S. bicolor red leaves

\begin{tabular}{|c|c|c|c|}
\hline Compound & $\begin{array}{l}\text { Hexane-methanol } \\
\text { oil-like fraction }(\%)^{a}\end{array}$ & 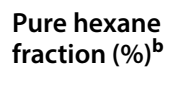 & $\begin{array}{l}n \text {-Hexane } \\
\text { crude oil-like } \\
\text { extract }(\%)^{c}\end{array}$ \\
\hline Ethylformate & 0.07 & $\operatorname{Tr}$ & ni \\
\hline Isobutyric acid & 0.04 & 0.58 & ni \\
\hline Oxalic acid & 0.05 & nd & 7.87 \\
\hline Benzoic acid & 11.33 & 4.68 & 14.66 \\
\hline Tyrosol & 1.40 & 2.71 & 1.69 \\
\hline Octanoic acid & ni & ni & 13.95 \\
\hline Cinnamic acid & ni & ni & 3.31 \\
\hline Vanillic acid & 2.11 & 3.88 & 1.00 \\
\hline Decanoic acid & ni & nd & 2.07 \\
\hline Caffeic acid & 0.26 & 5.08 & 2.46 \\
\hline Quinic acid & ni & ni & 2.77 \\
\hline Ferulic acid & ni & 6.78 & 2.16 \\
\hline $\begin{array}{l}n \text {-Hexadecanoic } \\
\text { acid }\end{array}$ & ni & ni & 3.70 \\
\hline Heptanoic acid & nd & ni & 0.49 \\
\hline Myristic acid & 0.05 & ni & 1.33 \\
\hline Nonadecane & 0.03 & ni & ni \\
\hline $\begin{array}{l}\text { Nonadecanoic } \\
\text { acid }\end{array}$ & ni & ni & 8.51 \\
\hline Palmitoleic acid & ni & ni & 1.85 \\
\hline $\begin{array}{l}\text { Indole-3-acetic } \\
\text { acid }\end{array}$ & ni & ni & 0.88 \\
\hline Apigenin & 31.27 & ni & 0.75 \\
\hline Naringenin & 2.71 & 0.97 & 0.16 \\
\hline $\begin{array}{l}\text { Gamma-Linoleic } \\
\text { acid }\end{array}$ & 1.26 & ni & 0.40 \\
\hline Linoleic acid & 1.26 & 0.19 & 1.08 \\
\hline Stearic acid & ni & ni & 2.27 \\
\hline Luteolin & 25.28 & 2.91 & 9.40 \\
\hline Gadoleic acid & nd & ni & 0.91 \\
\hline Malvidin & nd & ni & 0.62 \\
\hline Carsonic acid & nd & ni & 0.66 \\
\hline Rosmanol & nd & ni & 0.65 \\
\hline Malic acid & nd & 7.86 & ni \\
\hline Ethylpropionate & nd & 1.94 & 0.06 \\
\hline Caproic acid & nd & 7.13 & $\operatorname{Tr}$ \\
\hline Alpha-thujene & nd & 4.32 & $\operatorname{Tr}$ \\
\hline $\begin{array}{l}\text { 3,4-Dihydroxy- } \\
\text { benzoic acid }\end{array}$ & nd & 4.11 & $\operatorname{Tr}$ \\
\hline Alpha-terpineol & 0.06 & 3.10 & $\operatorname{Tr}$ \\
\hline Hydroxytyrosol & 0.96 & ni & $\operatorname{Tr}$ \\
\hline Nonanoic acid & $n / i$ & 3.10 & $\operatorname{Tr}$ \\
\hline Undecylic acid & $\mathrm{n} / \mathrm{i}$ & 0.87 & $\operatorname{Tr}$ \\
\hline Jasmonic acid & 0.74 & 22.93 & $\operatorname{Tr}$ \\
\hline $\begin{array}{l}9,10 \text { di-Jasmonic } \\
\text { acid }\end{array}$ & nd & 1.74 & $\operatorname{Tr}$ \\
\hline Tridecylic acid & $\mathrm{n} / \mathrm{i}$ & 0.97 & $\operatorname{Tr}$ \\
\hline Nonane & $\mathrm{n} / \mathrm{i}$ & 9.88 & $\operatorname{Tr}$ \\
\hline
\end{tabular}


Table 1 (continued)

\begin{tabular}{|c|c|c|c|}
\hline Compound & $\begin{array}{l}\text { Hexane-methanol } \\
\text { oil-like fraction (\%) }\end{array}$ & $\begin{array}{l}\text { Pure hexane } \\
\text { fraction }(\%)^{\mathbf{b}}\end{array}$ & $\begin{array}{l}n \text {-Hexane } \\
\text { crude oil-like } \\
\text { extract }(\%)^{c}\end{array}$ \\
\hline Palmitic acid & 0.88 & 0.78 & $\operatorname{Tr}$ \\
\hline Hesperidin & $n / i$ & 0.97 & $\mathrm{Tr}$ \\
\hline Citronellal & 0.02 & nd & $\mathrm{Tr}$ \\
\hline Pelargonic acid & 0.01 & nd & $\operatorname{Tr}$ \\
\hline Eugenol & 3.25 & nd & $\operatorname{Tr}$ \\
\hline Coumaric acid & 0.77 & nd & $\mathrm{Tr}$ \\
\hline Apigeninidin & 0.05 & nd & $\mathrm{Tr}$ \\
\hline Lignoceric acid & 0.80 & nd & $\mathrm{Tr}$ \\
\hline $\begin{array}{l}\text { Alpha-linoleic } \\
\text { acid }\end{array}$ & 0.38 & nd & $\mathrm{Tr}$ \\
\hline Epicatechin & 1.37 & nd & $\mathrm{Tr}$ \\
\hline Catechin & 0.04 & nd & $\mathrm{Tr}$ \\
\hline EPA & 1.78 & nd & $\mathrm{Tr}$ \\
\hline Arachidonic acid & 9.57 & nd & $\mathrm{Tr}$ \\
\hline $\begin{array}{l}\text { Dihomo- } \gamma^{-} \\
\text {linolenic acid }\end{array}$ & 0.58 & nd & $\operatorname{Tr}$ \\
\hline $\begin{array}{l}\text { Coumaric acid } \\
\text { hexoside }\end{array}$ & 0.51 & nd & $\mathrm{Tr}$ \\
\hline $\mathrm{DHA}$ & 0.10 & nd & ni \\
\hline Campesterol & 0.05 & nd & ni \\
\hline $\begin{array}{c}\text { Ellagic acid } \\
\text { hexoside }\end{array}$ & 0.03 & nd & ni \\
\hline $\begin{array}{l}\text { Ellagic acid } \\
\text { pentoside }\end{array}$ & 0.07 & nd & ni \\
\hline $\begin{array}{l}\text { Epicatechin } \\
\text { 3-O-gallate }\end{array}$ & 0.07 & nd & ni \\
\hline $\begin{array}{l}\text { Valoneic acid } \\
\text { dilactone }\end{array}$ & 0.06 & nd & ni \\
\hline $\begin{array}{l}\text { Quercetin pen- } \\
\text { toside }\end{array}$ & 0.24 & nd & ni \\
\hline
\end{tabular}

nd not determined, ni not identified, $\operatorname{Tr}$ trace amount, ${ }^{a}$ of $3.0 \mathrm{mg} / \mathrm{mL}^{\mathrm{b}}{ }^{\mathrm{b}}$ of $6.8 \mathrm{mg} / \mathrm{mL}$ and ${ }^{\mathrm{C}}$ of $6.6 \mathrm{mg} / \mathrm{mL}$

$\mathrm{IC}_{50 \mathrm{p}}$ for parasites, the selectivity index (SI) value determined for the crude extract was greater than of the hexane-methanol fraction, suggesting that the crude oil-like extract of $S$. bicolor would have broader spectrum and better potency against the parasites than the fractions (Table 2).

\section{Discussion}

The non-availability of safe and effective vaccine or drugs to completely eradicate neglected infectious diseases is still a major global challenge, partly because of the emerging drug-resistant strains of pathogens, coupled with toxicity and hypersensitivity of some current drugs. Hence, there is an urgent need to develop new effective and safe antitoxoplasmosis drugs from ethnomedicinal plants. Here, we investigated the inhibitory activity of oil-like extracts from dried S. bicolor red leaf
Table 2 In vitro anti-Toxoplasma gondii growth inhibitory effect $(\mu \mathrm{g} / \mathrm{mL})$, cytotoxic activity $(\mu \mathrm{g} / \mathrm{mL})$, and selective indexes for $S$. bicolor red leaf oil-like extract and fractions

\begin{tabular}{llll}
\hline Compound & $\mathbf{C C}_{\mathbf{5 0}}(\mathbf{9 5 \%} \mathbf{C l})$ & $\mathbf{I C}_{\mathbf{5 0}}(\mathbf{9 5} \% \mathbf{C I})$ & $\mathbf{S I}$ \\
\hline $\begin{array}{l}\text { S. bicolor n-hexane crude } \\
\text { extract }\end{array}$ & $34.41(31.62-37.45)$ & $3.65(2.07-6.45)$ & 9.43 \\
$\begin{array}{l}\text { Hexane-methanol (10:1) } \\
\text { fraction of crude extract }\end{array}$ & $16.92(14.25-20.10)$ & $2.74(0.71-10.54)$ & 6.18 \\
$\begin{array}{l}\text { Hexane fraction of crude } \\
\text { extract }\end{array}$ & $7.23(3.24-16.14)$ & $3.55(0.73-17.20)$ & 2.04 \\
\hline
\end{tabular}

95\% Cl 95\% confidence interval for means of triplicate independent assays, $\mathrm{CC}_{50}$ concentration of oil-like extract that caused $50 \%$ reduction in viability of human foreskin fibroblasts, $I C_{50}$ minimum inhibitory concentration of crude and fractionated oil-like substance that inhibits $50 \%$ T. gondii tachyzoite growth, $S I$ selectivity index

against $T$. gondii tachyzoites. The $S$. bicolor oil-like crude extracts and fractions were found to significantly inhibit T. gondii tachyzoites growth in vitro. Generally, the cytotoxicity levels of the different fractions were twofold ( $n$ hexane fraction), sixfold ( $n$ hexane-methanol fraction) and ninefold (crude extract) greater than the $T$. gondii effective inhibitory concentrations. These observations suggest that, despite having had potent activity against T. gondii, S. bicolor oil-like crude and fractions may not pose adverse side effects against mammalian cells. This unique activity of S. bicolor red leaf oil-like crude extracts and fractions could be partly attributed to the presence of benzoic, octanoic, nonadecanoic, linoleic, palmitic, stearic, oleic, arachiodonic, ferulic, caffeic acid, quinic and jasmonic acid, as well as luteolin, apigenin and eugenol. Studies of antibacterial, antifungal, antiviral and antiprotozoal activities of some essential oils have been reported [25-27]. However, the compounds composition in the extracts reported earlier are not similar to the ones found in the present study. Importantly, the oil-like extracts and fractions obtained from the S. bicolor leaf were observed to have high potent anti- $T$. gondii activity than other essential oils antiprotozoal studies reported [26-28]. This could be attributed to the presence of the 3-deoxyanthocyanidin compounds that have been previously reported from the sorghum leaf to have remarkable antiparasitic activity [22]. In comparison, the $\mathrm{IC}_{50}$ values against $T$. gondii for the various oil-like fractions reported in this paper were lower than some of those reported by several authors in different medicinal plant extracts [27-29].

Nevertheless, further studies would be important to determine the cytotoxic effects of the S. bicolor crude oil-like extract and its fractions in additional mammalian cell lines. Notwithstanding, the S. bicolor oillike extracts and fractions investigated in this study exhibited strong anti-Toxoplasma gondii activity with 

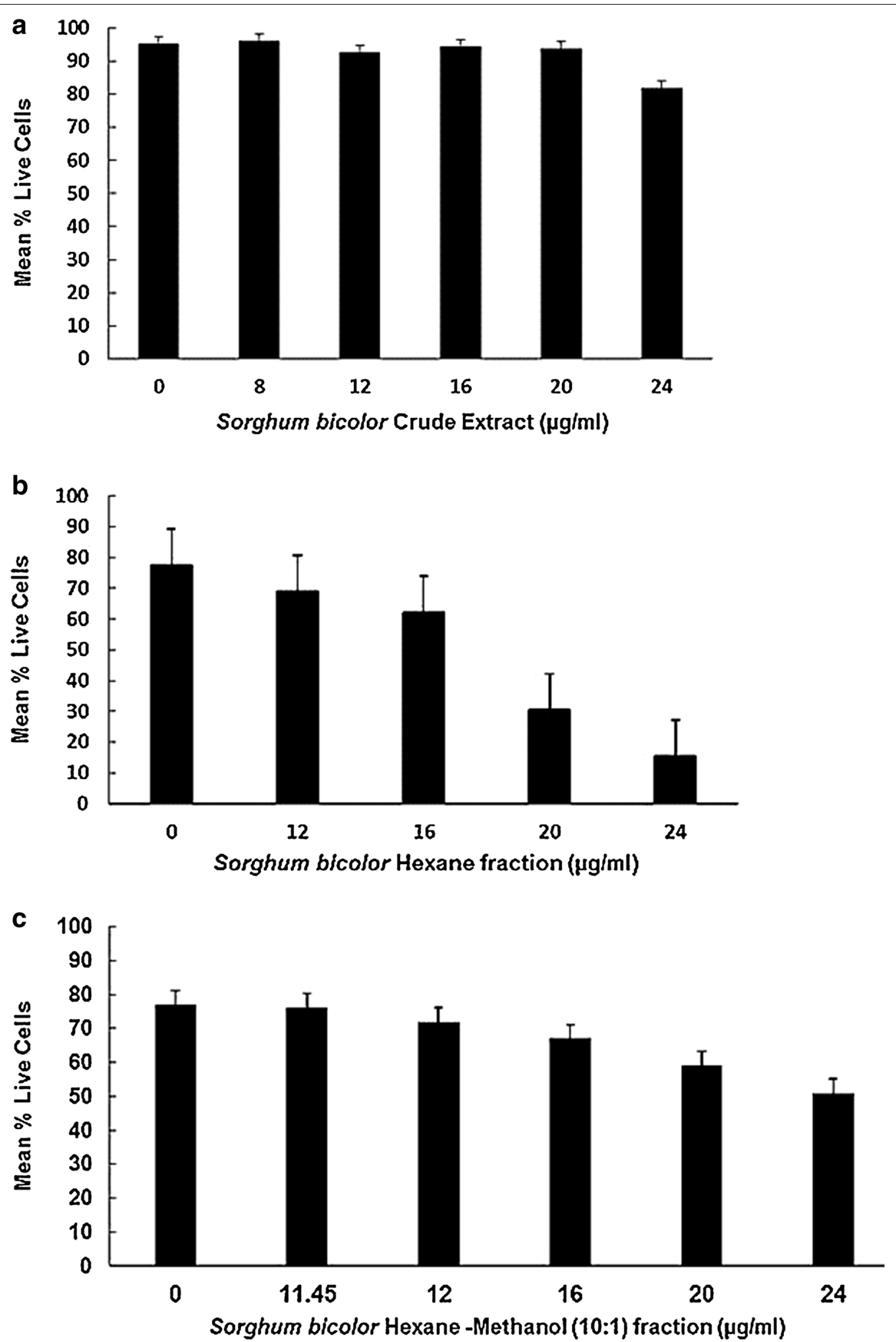

Fig. 1 a Cytotoxic effects of lipophilic S. bicolor leaves crude extract on Human foreskin fibroblasts cells. b Cytotoxic effects of the hexane fraction from the lipophilic Sorghum bicolor extract on human foreskin fibroblast cells. cCytotoxic effects of the hexane-methanol (10:1) fraction from the lipophilic Sorghum bicolor extract on human foreskin fibroblast cells 
low cytotoxic effects against a human cell line (HFF). Eugenol, a compound we found in significant amounts in the S. bicolor extract has been shown to have antiGiardia, antibacterial, antifungal and antioxidant properties, as well as curative effects in skin, prostate and melanoma cancers [30,31]. On the other hand, luteolin and apigenin have also been reported to have anticancer, antibacterial and anti-leishmania activities [32, 33]. Tasdemir et al. [33], also attested that phenolic acids such as coumaric acid, caffeic acid, ferulic acid and cinnamic acid have effective in vitro leishmanicidal activity.

Taken together, immunocompromised persons such as cancer patients may derive multiple benefits from $S$. bicolor essential oils in fighting cancer and any $T$. gondii opportunistic coinfections.

\section{Limitations}

The $S$. bicolor oil-like crude extracts and fractions has potency against the tachyzoite stage, and it will be interesting to determine if it may also have activity against the encysted bradyzoite stage of $T$. gondii. It will also be important to study the S. bicolor oil-like crude extracts and fractions further in order to identify the individual compounds responsible for the anti- $T$. gondii activity and determine their mechanism of action individually or in combinations for the development of novel inhibitors against $T$. gondii and other pathogens.

\section{Abbreviations \\ DMSO: dimethyl sulfoxide; DWB: dry weight basis; FBS: fetal bovine serum; HFF: human foreskin fibroblasts; HIV-AIDS: human immunodeficiency virus and acquired immune deficiency syndrome; $I C_{50 p}$ : minimum inhibitory concentrations against $T$. gondii tachyzoites; $I C_{50}$ : the minimum cytotoxicity concentrations against HFF; IMDM: Iscove's modified Dulbecco's medium; TLC: thin layer chromatography; RH-YFP: yellow fluorescent protein; SI: selectivity index; NIH: National Institute of Health; US: United States.}

\section{Acknowledgements}

We wish to express our gratitude to the Department of Chemistry at Tuskegee University for their support in the plant material extraction. In addition, we acknowledge the support of the RCMI core Lab team for assisting us with the microscopy analyzes. The core facility was established with Grant Number G12MD007585-23.

\section{Authors' contributions \\ DAA performed the experiments, collected the raw data, analyzed the data using ImageJ and GraphPad prism, interpretation of data, wrote the first draft under the guidance of JMJ and WHW. WHW and JMJ all contributed substan- tial to the experimental design, interpretation of the data and revised the drafted manuscript. All authors read and approved the final manuscript.}

\section{Funding}

Not applicable.

\section{Availability of data and materials}

The datasets used and/or analyzed during the current study are available from the corresponding author on reasonable request.
Ethics approval and consent to participate Not applicable.

\section{Consent to publish}

Not applicable.

\section{Competing interests}

The authors declare that they have no competing interests.

\section{Author details}

${ }^{1}$ Department of Chemistry and Department of Biology, Laboratory of Ethnomedicine, Parasitology and Drug Discovery, College of Arts and Sciences, Tuskegee University, Tuskegee, AL, USA. ${ }^{2}$ Department of Agricultural and Environmental Sciences, College of Agriculture, Environment and Nutrition Sciences, Tuskegee University, Tuskegee, AL 36088, USA. ${ }^{3}$ Department of Pathobiology, College of Veterinary Medicine, University of Illinois, Urbana-Champaign, IL 61802, USA.

Received: 15 August 2019 Accepted: 14 October 2019

Published online: 24 October 2019

\section{References}

1. Dubey JP, Beattie CP. Toxoplasmosis in man (Homo sapiens). Toxoplasmosis of animals and man. Boca Raton: CRC Press, Inc.; 1988. p. 1-336.

2. Zhang M, Yang Z, Wang S, Tao LF, Xu L, Song RX, Li X. Detection of Toxoplasma gondii in shellfish and fish in parts of China. Vet Parasitol. 2014:200:85-9.

3. Flegr J, Prandota J, Soviekova M, Israili ZH. Toxoplasmsosis-a global threat. Correlation of latent toxoplasmsosis with specific disease burden in a set of 88 countries. PLOS ONE. 2014;9:e90203.

4. Dubey JP. Toxoplasmosis - a waterborne zoonosis. Vet Parasitol. 2006; 126:57-72.

5. Tenter AM, Heckeroth AR, Weiss LM. Toxoplasma gondii: from animals to humans. Int J Parasitol. 2000;30:1217-58.

6. Pappas G, Roussos N, Falagas ME. Toxoplasmosis snapshots: global status of Toxoplasma gondii seroprevalence and implications for pregnancy and congenital toxoplasmosis. Int J Parasitol. 2009;39:1385-94.

7. Mazzillo FFM, Shapiro K, Silver MW. A new pathogen transmission mechanism in the Ocean: the case of sea otter exposure to the land-parasite Toxoplasma gondii. PLoS ONE. 2013;8:e82477.

8. National Institute of Allergy and Infectious Diseases (NIAID). Biodefense microorganisms. 2014. http://www.niaid.nih.gov/topics/biodefenserelat ed/biodefense/pages/cat.aspx. Accessed 22 Jan 2015.

9. Center for Disease Control and Prevention (CDC). Toxoplasmosis updates. 2015. http://www.cdc.gov/parasites/toxoplasmosis/epi.html. Accessed 22 Mar 2015.

10. Hughes J, Colley D. Preventing congenital toxoplasmosis. Center for Disease Control. 2000. http://www.cdc.gov/mmwr/preview/mmwrhtml/ rr4902a5.htm.

11. Alday H, Doggett JS. Drug in development for toxoplasmosis: advances, challenges, and current status. Drug Des Dev Ther. 2017;11:273-93.

12. Boyom FF, Fokou PVT, Tchokouaha LRY, Spangenberg T, Mfopa AN, Kouipou RMT, Mbouna CJ, Donfack VFD, Zollo PHA. Repurposing the open access malaria box to discover potent inhibitors of Toxoplasma gondii and Entamoeba histolytica. Antimicrob Agents Chemother. 2014;58(10):5848-54.

13. Montazeri M, Sharif M, Sarvi S, Mehrzadi S, Ahmadpour E, Daryani A. A systematic review of in vitro and in vitro activities of anti-Toxoplasma drugs and compounds (2006-2016). Front Microbiol. 2017:8:1-31.

14. McLeod R, Khan AR, Noble GA, Latkany P, Jalbrzikowski J, Boyer K. Toxoplasmosis Study Group Severe sulfadiazine hypersensitivity in a child with reactivated congenital toxoplasmic chorioretinitis. Pediatr Infect Dis J. 2006;25:270-2.

15. Fomovska A, Huang Q, El Bissati K, Mui EJ, Witola WH, Cheng G, Prigge ST. Novel $\mathrm{N}$-benzoyl-2-hydroxybenzamide disrupts unique parasite secretory pathway. Antimicrob Agents Chemother. 2012;56:2666-82. 
16. Mui EJ, Schiehser GA, Milhous WK, Hsu H, Roberts CW, Kirisits M, Muench S, Rice D, Dubey JP, Fowble JW, Rathod PK. Novel triazine JPC-2067-B inhibits Toxoplasma gondii in vitro and in vivo. PLoS Negl Trop Dis. 2008;2:e190.

17. Hellmann JK, Munter S, Wink M, Frischknecht F. Synergistic and additive effects of epigallocatechin gallate and digitonin on Plasmodium sporozoite survival and motility. PLoS ONE. 2010;5:e8682.

18. Oladiji AT, Jacob TO, Yakubu MT. Anti-anaemic potentials of aqueous extract of Sorghum bicolor (L.) Moench stem bark in rats. J Ethnopharmacol. 2007;111:651-6.

19. Filho IC, Cortez DA, Ueda-Nakamura T, Nakamura CV, Dias Filho BP. Antiviral activity and mode of action of a peptide isolated from Sorghum bicolor. Phytomedicine. 2008;15:202-8.

20. Abugri DA, Tiimob JB, Apalagya VA, Pritchett G, McElhenney WH. Bioactive and nutritive compounds in Sorghum bicolor (Guinea corn) red leaves and their health implication. Food Chem. 2013;138:718-23.

21. Abugri DA, Akudago JA, Pritchett G, Russell AE, McElhenney WH. Comparison of phytochemical compositions of Sorghum bicolor (L.) Moench red flour and pale brown leaves. Food Sci Nutr. 2015;1:1-5.

22. Abugri DA, Witola WH, Jaynes JM, Toufic N. In vitro activity of Sorghum bicolor extracts, 3-deoxyanthocyanidins, against Toxoplasma gondii. Exp Parasitol. 2016;164:12-9.

23. Ayuba Gl, Jensen GS, Benson KF, Okubena AM, Okubena O. Clinical efficacy of a West African Sorghum bicolor-based traditional herbal preparation Jobelyn shows increased hemoglobin and $\mathrm{CD}^{+}{ }^{+}$T-lymphocyte counts in HIV-positive patients. J Altern Complement Med. 2014;20:53-6.

24. Wang Q, Cheng X-L, Li H, Quin X-Y, Ge C-Y, Liu R, Qi L-W, Qin M-J. Application of an efficient strategy for discovery and purification of bioactive compounds from Chinese herbal medicines, a case study on the Puerariae thomsonii Flos. J Pharm Biomed Anal. 2013;75:25-32.

25. Goulart HR, Kimura EA, Peres VJ, Couto AS, Fulgencio AAD, Katzin AM. Terpenes arrest parasite development and inhibit biosynthesis of isoprenoids in Plasmodium falciparum. Antimicrob Agents Chemother. 2004:48:2502-9.
26. Orhan I, Aslan M, Sener B, Kaiser M, Tasdemir D. In vitro antiprotozoal activity of the lipophilic extracts of different parts of Turkish Pistacia vera L. Phytomedicine. 2006:13:735-9.

27. Pillai S, Mahmud R, Lee WC, Perumal S. Anti-parasitic activity of Myristica fragrans Houtt. essential oil against Toxoplasma gondii parasite. APCBEE Procedia. 2012;2:92-6.

28. Lee WC, Mahmud R, Noordin R, Piaru SP, Perumal S, Ismail S. Free radicals scavenging activity, cytotoxicity and anti-parasitic activity of essential oil of Psidium guajava L. leaves against Toxoplasma gondii. J Essent Oil Bear Plants. 2015;1(16):32-8.

29. Daryani A, Ebrahimzadeh MA, Sharif M, Ahmadpour E, Edalatian S, Esboei B, Sarvi S. Anti-Toxoplasma activities of methanolic extract of Sambucus nigra (Caprifoliaceae) fruits and leaves. Rev Biol Trop. 2015;63:7-12.

30. Machado M, Dinis AM, Salgueiro L, Custódio JB, Cavaleiro C, Sousa MC. Anti-Giardia activity of Syzygium aromaticum essential oil and eugenol: effects on growth, viability, adherence and ultrastructure. Exp Parasitol. 2011;127:732-9.

31. Kang X, Liu X, Li J, Yang Y. Advances in pharmacological research of Eugenol. Curr Opin Complement Altern Med. 2014;1:8-11.

32. Mittra B, Saha A, Chowdhury AR, Pal C, Mandal S, Mukhopadhyay S, Bandyopadhyay S, Majumder HK. Luteolin, an abundant dietary component is a potent anti-leishmanial agent that acts by inducing topoisomerase II-mediated kinetoplast DNA cleavage leading to apoptosis. Mol Med. 2000;6:527-41.

33. Tasdemir D, Kaiser M, Brun R, Yardley V, Schmidt TJ, Tosun F, Ruedi P. Antitrypanosomal and antileishmanial activities of flavonoids and their analogues: in vitro, in vivo, structure-activity relationship, and quantitative structure-activity relationship studies. Antimicrob Agents Chemother. 2006:50:1352-64.

\section{Publisher's Note}

Springer Nature remains neutral with regard to jurisdictional claims in published maps and institutional affiliations.
Ready to submit your research? Choose BMC and benefit from:

- fast, convenient online submission

- thorough peer review by experienced researchers in your field

- rapid publication on acceptance

- support for research data, including large and complex data types

- gold Open Access which fosters wider collaboration and increased citations

- maximum visibility for your research: over $100 \mathrm{M}$ website views per year

At BMC, research is always in progress.

Learn more biomedcentral.com/submissions 